\title{
PENYIMPANGAN SEKSUAL (LGBT) DALAM PANDANGAN HUKUM ISLAM
}

\author{
Huzaemah Tahido Yanggo \\ IIQ Jakarta \\ misykat_iiq@yahoo.com
}

\begin{abstract}
Abstrak
Masalah penyimpangan seksual (lesbian, gay, biseksual dan transgender) sedang dalam perdebatan yang hangat dibicarakan dalam masyarakat, mulai dari media cetak dan elektronik, ada dari kalangan tokoh Islam sendiri yang membolehkan homo dan lesbi, dengan dasar bahwa tidak ada perbedaan antara homo dan bukan homo dan tidak ada perbedaan antara lesbi dan bukan lesbi. Menurut mereka bahwa manusia cuma bisa berlomba berbuat amal kebajikan sesuai perintah Tuhan. Islam mengajarkan bahwa seorang homo atau lesbi sebagaimana manusia lainnya, sangat berpotensi menjadi orang yang saleh atau takwa selama dia menjunjung tinggi nilai-nilai agama, yaitu tidak menduakan Tuhan (syirik), meyakini kerasulan Muhammad Saw serta menjalankan ibadah yang diperintahkan. Dia tidak menyakiti pasangannya dan berbuat baik kepada sesama manusia, kepada sesama makhluk dan peduli kepada lingkungannya. Bahkan menurutnya, menarik sekali membaca ayat-ayat Al-Qur'an soal hidup berpasangan (Q.S. al-Rum : 21, Q.S al-Dzariyat : 49 dan Q.S Yasin : 36) di sana tidak dijelaskan soal jenis kelamin biologis, yang ada hanyalah soal gender. Artinya, berpasangan itu tidak mesti dalam konteks hetero, melainkan bisa homo, dan bisa lesbi.

Sekarang ini Indonesia semakin liberal. Orang-orang homo dan lesbi semakin giat mengekspos perbuatannya secara terbuka, bahkan berusaha mencari legitimasi dalil dari A1-Qur'an, memelintir maknanya dengan tidak melihat kepada ayat-ayat yang lain yang berkenaan dengan masalah yang ada. Pada hal ayat-ayat Al-Qur'an saling menafsirkan antara satu ayat dengan ayat lainnya. Hal ini disebabkan karena mereka hanya memiliki sedikit ilmu pengetahuan agama, belum banyak membaca tafsir dan Hadis, tidak mengetahui ushul fiqh dan sarana-sarana ijtihad yang lainnya, sehingga menurut mereka tidak ada larangan dari Al-Qur'an dan Hadis untuk melakukan homoseksual dan lesbian sehingga menurut mereka, bahwa pelarangan terhadap LBGT adalah pelarangan terhadap HAM. Berkenaan dengan masalah ini, maka dalam artikel ini akan dibahas bagaimana pandangan hukum Islam terhadap penyimpangan seksual (LGBT). Adapun pembahasan berkisar pada pengertian homoseksual, lesbian dan hukumnya menurut pandangan Islam dan sanksi atas pelakunya dampak negatif yang ditimbulkannya dan upaya penanggulangannya.
\end{abstract}

Kata Kunci : Penyimpangan Seksual; LGBT; Hukum Islam 


\section{A. Pengertian Homoseksual (gay) dan Lesbian serta Hukumnya}

Islam sangat memperhatikan kesucian dan kehalalan. Agar manusia sehat dan cerdas secara emosional, intelektual dan spiritual maka semua yang dikonsumsi haruslah memenuhi kriteria suci dan halal.

1) Pengertian homoseksual

Homoseksual (gay) di dalam agama Islam disebut dengan istilah "al-liwath" (اللواط) yang berarti orang yang melakukan perbuatan seperti perbuatan kaum Nabi Luth, yang pelakunya disebut "al-luthiyyu" (اللوطي), yang berarti laki-laki yang melakukan hubungan seksual dengan laki-laki. ${ }^{1}$

2) Pengertian Lesbian

Istilah lesbian di dalam agama Islam disebut dengan "al-sihaq" (السحاق) yang berarti perempuan yang melakukan hubungan seksual dengan sesama perempuan.2

Dari pengertian tersebut dapat ditarik kesimpulan bahwa homoseksual ialah hubungan seksual antara laki-laki dengan lakilaki, sedangkan untuk berhubungan seks antara wanita, disebut lesbian (female homosex). Lawan homosex dan lesbian adalah heterosex, artinya hubungan seksual antara orang-orang yang berbeda jenis kelaminnya (seorang pria dengan seorang wanita).

Dalam hukum Islam, homoseks sesama pria disebut liwath yang akar katanya sama dengan akar kata Luth. Perbuatan homoseks sesama pria itu disebut liwath, karena perbuatan tersebut pernah dilakukan oleh kaum yang durhaka kepada seruan Nabi Luth as. Kaum itu berdomisili di negeri Sodom (di sebelah timur Laut Mati atau di Yordania sekarang) dan karena itu di kalangan bangsa Barat yang beragama Kristen perbuatan demikian disebut sodomi. ${ }^{3}$ Dalam berbagai referensi semua mengatakan, bahwa homoseksual adalah kebiasaan seorang lakilaki melampiaskan nafsu seksualnya pada sesamanya. Sedangkan lesbian adalah kebiasaan seorang perempuan melampiaskan nafsu seksualnya pada sesamanya.

\footnotetext{
${ }^{1}$ Majma' al-Lughah al-'Arabiyah, al-Mu'jam al-Wasith, cet. II, Jilid II, (Mishr : Dar al-Ma'arif, 1393 H- 1973 M), 846.

2 Ahmad Warson Munawwir, Kamus Al-Munawir, cet. XIV (Surabaya; Pustaka Progressif, 1997), 616; al-Sayid Sabiq, Fiqh al-Sunnah, Jilid II, (alQahirah; Dar al-Kitab al-Islamy-Dar al-Hadis, t.t), 269.

3 Abd. Aziz Dahlan, et.al., (editor), Ensiklopedi Hukum Islam, Jilid II (Jakarta : PT. Ikhtiar Van Hoeve, 1996), 563.
} 


\section{B. Hukum Penyimpangan Seksual (LGBT) Menurut Islam}

Pasangan homoseks dalam bentuk liwath termasuk dalam tindak pidana berat (dosa besar), karena termasuk perbuatan keji yang merusak kepribadian, moral dan agama. Hal ini sesuai dengan firman Allah dalam Q.S al-A'raf ayat (7) : 80 dan 81 sebagai berikut :

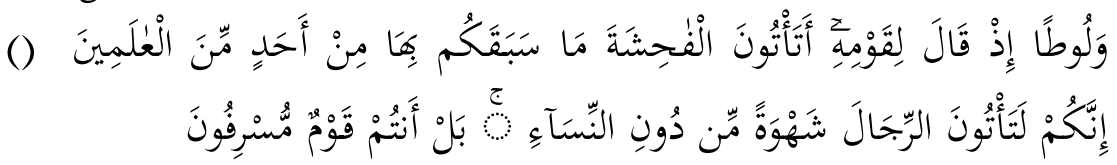

Artinya: "Dan (kami juga telah mengutus) Luth ketika dia berkata kepada mereka: "mengapa kamu mengerjakan perbuatan keji, yang belum pernah dikerjakan oleh seorangpun (di dunia ini)". Sesungguhnya kamu mendatangi lelaki untuk melepaskan nafsumu (kepada mereka), bukan kepada wanita, malah kamu ini adalah kaum yang melampaui batas".

Senada dengan ayat-ayat tersebut, juga disebutkan dalam Q.S al-Syu'ara' (26) : ayat 165 dan 166 sebagai berikut:

$$
\text { أَتَاتَتُونَ النُُْْرَانَ مِنَ الْعَلَمِينَ }
$$

Artinya : "Luth berkata kepada kaumnya): Mengapa kamu mendatangi (menggauli jenis laki-laki) di antara manusia" (QS. al-Syuara':165)

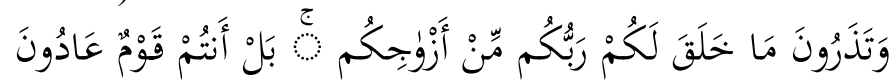

Artinya: "Dan kamu tinggalkan isteri-isteri yang dijadikan oleh Tuhanmu untukmu, bahkan kamu adalah orangorang yang melampaui batas". (QS. al-Syuara':166).

Ayat-ayat yang telah disebutkan menerangkan bahwa perbuatan kaum Nabi Luth yang hanya melakukan hubungan seksual kepada sesama laki-laki melepaskan syahwatnya hanya kepada sesama laki-laki dan tidak berminat kepada perempuan sebagaimana ditawarkan oleh Nabi Luth, tetapi mereka tetap melakukan perbuatan homoseksual, akhirnya Allah memberikan hukuman kepada mereka dan memutarbalikan negeri mereka, sehingga penduduk Sodom, termasuk isteri Nabi Luth kaum lesbi, tertanam bersamaan dengan terbaliknya negeri itu. Yang tidak kena azab hanya Nabi Luth dan pengikut-pengikutnya yang saleh dan menjauhkan diri dari perbuatan homoseks. 
Ulama fikih sepakat mengharamkan homoseks selain berdasarkan Al-Qur'an dan Hadis, juga berdasarkan kaidah fiqhiyah yang mengatakan :

$$
\text { الأصل في الابضاع التحريم حتى يدل دليل إباحته }
$$

Artinya : "Hubungan seks pada dasarnya adalah haram, sehingga ada dalil (sebab-sebab yang jelas dan yakin tanpa keraguan) yang menghalalkannya, yakni adanya akad nikah".

Begitu pula ulama fikih sepakat mengharamkan perbuatan lesbian, berdasarkan Hadis Nabi Saw yang diriwayatkan oleh Muslim dari Abi Said.

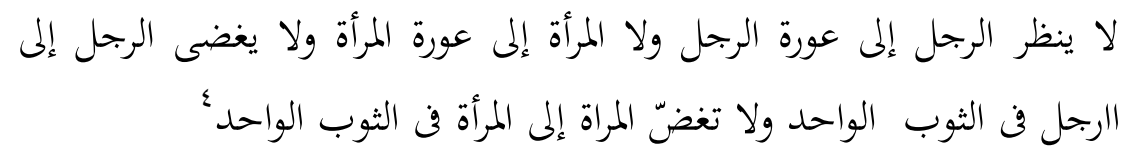

Artinya: "Janganlah pria melihat aurat pria lain dan janganlah wanita melihat aurat wanita lain dan janganlah bersentuhan pria dengan pria lain di bawah sehelai selimut/kain, dan janganlah pula wanita bersentuhan dengan wanita lain di bawah sehelai selimut/kain".

Dari uraian di atas dapat disimpulkan, bahwa perbuatan homo dan lesbi haram hukumnya, apakah itu berbentuk pasangan menikah atau tidak. Kalau ada ungkapan atau pernyataan yang mengatakan bahwa homo dan lesbi dibolehkan, itu bukan ajaran Al-Qur'an dan Hadis dan bukan pula hasil ijtihad ulama yang mumpuni dibidangnya. Itu hanya ungkapan dan pernyataan dari kalangan liberal yang hanya berbekal sedikit pengetahuan agama, yang belum mengkaji dengan baik ayat-ayat Al-Qur'an dan Hadis, sehingga mereka memberi fatwa yang menyesatkan, yaitu mengabsahkan perilaku homoseksual dan lesbi.

Larangan homoseksual dan lesbian bukan hanya karena merusak kemuliaan dan martabat kemanusiaan, tetapi resikonya lebih besar lagi, yaitu dapat menimbulkan penyakit kanker kelamin HIV/AIDS, spilis, dan lain-lain. Demikian pula perkawinan waria yang telah menjalani operasi penggantian kelamin dengan laki-laki, dikategorikan sebagai praktek homoseksual, karena tabiat kelaki-lakiannya tetap tidak bisa berubah oleh dokter, meskipun ia sudah memiliki kelamin perempuan.

\footnotetext{
${ }^{4}$ Muslim, Shahih Muslim, Jilid I (Cairo: Dar al Hadits, 1997), 277.
} 
Allah memurkai tingkah laku laki-laki yang mempunyai sifat keperempuanan dan sebaliknya, sebagaimana sabda Rasulullah Saw sebagai berikut :

$$
\text { قَالَ رسول الله لا ينظر الله الى رجل اتى رجلا او امراة في الدبر (رواه الترمذى) : }
$$

Artinya : Rasululah bersabda: "Allah tidak melihat seorang laki-laki yang mendatangi laki-laki (melakukan hubungan sex dengan sesamanya) dan mendatangi (menggauli) isteri melalui dubur)." (HR. al Tirmidzi).

Dalam Hadis yang lain Rasulullah Saw bersabda

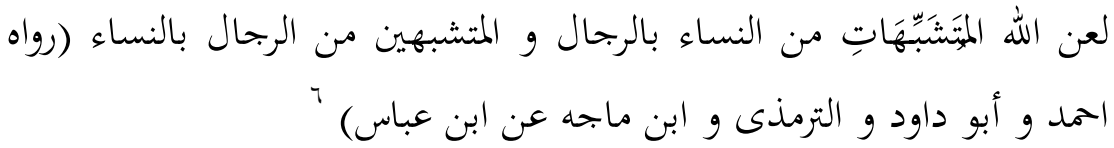

Artinya: "Allah mengutuk perempuan yang menyerupai laki-laki dan laki-laki menyerupai perempuan. (HR. Ahmad, Abu Daud, al-Tirmidzi dan Ibnu Majah dari Ibnu Abbas)

Dari Hadis-Hadis yang telah disebutkan menunjukkan bahwa laki-laki tidak boleh menyerupai perempuan dan sebaliknya. Tidak di kutuk oleh Allah perbuatannya itu melainkan karena perbuatan itu dilarang. Kalau dilarang mengerjakannya, maka hukumnya haram.

Berkenaan dengan laki-laki yang mempunyai sifat keperempuanan dan sebaliknya dianggap kalangan liberal sebagai "given" atau pemberian Tuhan. Benar memang segala sesuatu adalah dari Allah, tetapi perbuatan Allah itu, ada yang sifatnya karena ikhtiar dari manusia itu sendiri. Laki-laki yang mempunyai sifat keperempuanan dan sebaliknya, itu bisa terbentuk dari lingkungannya sejak kecil. Kalau lingkungan keluarga membiarkan anak laki-laki bergaul dengan anak perempuan terus-menerus, bahkan mengikuti pakaian, atau aktivitasnya, maka anak laki-laki itu akan terbiasa mengikuti sifat-sifat anak perempuan. Begitu pula sebaliknya. Walaupun ada anak laki-laki seperti tingkah laku perempuan, atau memiliki sifat perempuan dan sebaliknya, tetapi orang tuanya dapat mengarahkannya menjadi seorang laki-laki atau seorang perempuan sesuai dengan jenis kelamin anak.

\footnotetext{
${ }^{5}$ Al-Tirmidzi, Sunan Al-Tirmidzi (Bairut : Dar al Fikr, 1994), 89.

${ }^{6}$ Jalaluddin al-Suyuthy, al-Jami' al-Shaghir, Jilid II (Bairut-Libanon : Dar al-Kutub al-Ilmiyah, t.t.), 124.
} 


\section{Penafsiran Q.S Surah al-Rum : 21, Yasin : 36 dan al- Dzariyat : 49}

1) Q.S al-Rüm : 21 dan penafsirannya.

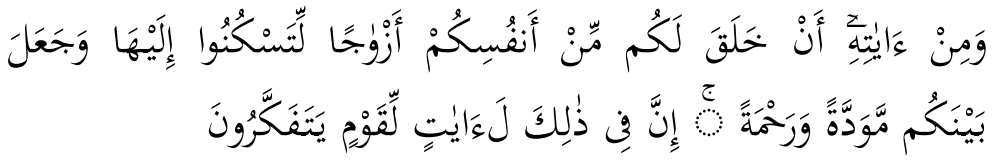

Artinya: "Dan di antara tanda-tanda kekuasaanNya ialah Dia mencipta-kan untukmu isteri-isteri dari jenismu sendiri, supaya kamu cenderung dan merasa tenteram kepadanya, dan dijadikan-Nya diantaramu rasa kasih dan sayang. Sesungguh-nya pada yang demikian itu benar-benar terdapat tanda-tanda bagi kaum yang berfikir".

Menurut Ibnu Katsir, bahwa pengertian ayat 21 al-Rum di atas, yaitu (dan di antara tanda-tanda kekuasaan-Nya ialah Dia menciptakan untukmu isteriisteri dari jenismu sendiri), yakni menciptakan kaum wanita dari jenismu sebagai pasangan hidup, (supaya kamu cenderung dan merasa tenteram kepadanya), yakni agar terciptalah keserasian di antara mereka, karena kalau pasangan itu bukan dari jenismu, maka timbullah keganjilan.

Maka di antara rahmat-Nya ialah Dia menciptakan kamu semua, laki-laki dan perempuan, dari jenis yang satu sehingga timbullah rasa kasih sayang, cinta dan senang. Karena itu, Dia berfirman, (dan dijadikan-Nya di antara kamu rasa kasih dan sayang), agar sarana-sarana keterikatan tetap terpelihara dan proses berketurunan pun berkesinambungan, (sesungguhnya pada yang demikian itu benar-benar terdapat tanda-tanda bagi kaum yang berpikir). ${ }^{7}$ Ibnu Katsir menafsirkan kata "أزو اجا" dengan makna isteri-isteri. Penafsiran Ibnu Katsir ini sama dengan penafsiran al-Qurthuby. ${ }^{8}$

${ }^{7}$ Ibnu Katsir, Tafsir Al-Qur'an al- 'Azhim, jilid III (t.tp.: Maktabah alTawfiqiyah, t.t), 429.

8 al-Qurthuby, al-Jami' li Ahkam al-Qur'an, cet III, Jilid XIII (t.tp.: t.p., t.t), 17. 
Sedangkan tafsir Depag RI menafsirkan ayat 21 al-Rum tersebut adalah bahwa ayat ini menerangkan tanda-tanda kekuasaan Allah (di antaranya), yaitu kehidupan bersama antara laki-laki dan perempuan dalam sebuah perkawinan. Manusia mengetahui bahwa mereka mempunyai perasaan tertentu terhadap jenis yang lain.

Perasaan dan pikiran-pikiran itu ditimbulkan oleh daya tarik yang ada pada masing-masing mereka, yang menjadikan yang satu tertarik kepada yang lain, sehingga antara kedua jenis, laki-laki dan perempuan, itu terjalin hubungan yang wajar. Mereka melangkah maju dan berusaha agar perasaan-perasaan dan kecenderungankecenderungan antara laki-laki dengan perempuan tercapai.

Puncak dari semuanya itu ialah terjadinya perkawinan antara laki-laki dengan perempuan. Dalam keadaan demikian, bagi laki-laki hanya isterinya perempuan yang paling baik, sedang bagi perempuan hanya suaminya laki-laki yang menarik hatinya. Masingmasing merasa tenteram hatinya dengan adanya pasangannya itu. Semuanya itu merupakan modal yang paling berharga dalam membina rumah tangga bahagia. ${ }^{9}$

M. Quraish Shihab menafsirkan ayat 21 al-Rum tersebut, sebagai berikut : "Dan juga di antara kekuasaan-Nya adalah Dia menciptakan untuk kamu secara khusus pasangan-pasangan hidup suami atau isteri dari jenis kamu sendiri, supaya kamu tenang dan tentram serta cenderung kepadanya, yakni kepada masing-masing pasangan itu, dan dijadikannya di antara kamu mawaddah dan rahmah. Sesungguhnya pada yang demikian itu benar-benar terdapat tanda-tanda bagi kaum yang berpikir tentang kuasa dan nikmat Allah." 10 2007), 481.

${ }^{9}$ Depag Rl, Al-Qur'an dan Tafsirnya, Jilid VII (Jakarta : Balitbang,

${ }^{10}$ M.Quraish Shihab, Tafsir al-Mishbah, cet I, Jilid XI (Jakarta : Lentera Hati, 1423 H-2003 M), 33, 34. 
Pada penafsiran M.Quraish Shihab, nampaknya kata "أزواجا" juga ditafsirkan sebagai pasangan, laki-laki dan perempuan. Dari beberapa orang mufassir yang telah disebutkan, ternyata penafsiran mereka terhadap kata " أززواجا" adalah berarti pasangan-pasangan yaitu isteri-isteri karena pasangan dalam perkawinan adalah laki-laki dan perempuan.

2) Q.S Yasin : 36 dan penafsirannya :

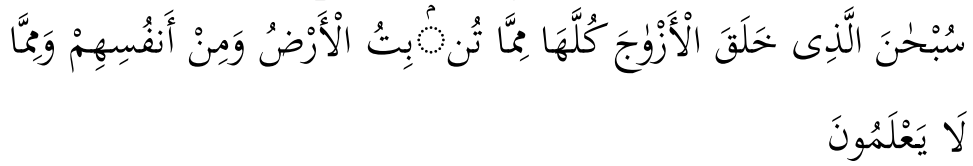

Artinya : "Maha Suci Tuhan yang telah menciptakan pasangan-pasangan semuanya, baik dari apa yang ditumbuhkan oleh bumi dan dari diri mereka maupun dari apa yang tidak mereka ketahui”.

M. Quraish Shihab menafsirkan ayat tersebut sebagai berikut: "Dialah Tuhan yang telah menciptakan pasangan-pasangan semuanya, pasangan yang berfungsi sebagai pejantan dan betina, baik dari apa yang ditimbulkan oleh bumi seperti kurma dan anggur, dan demikian juga dari diri mereka sebagai manusia, dimana mereka terdiri dari lelaki dan perempuan, dan demikian dari apa yang tidak atau belum mereka ketahui, baik makhluk hidup, maupun benda tak bernyawa. ${ }^{11}$

Selanjutnya M.Quraish Shihab mengatakan, bahwa dari segi bahasa, kata al-azwaj (الازواج) adalah bentuk jamak dari kata " zauj yakni pasangan. Kata ini menurut pakar bahasa Al-Qur'an, ar-Raghib alAshfahany, digunakan untuk masing-masing dari dua hal yang berdampingan (bersamaan), baik jantan maupun betina, binatang (termasuk binatang berakal yakni manusia) dan juga digunakan menunjuk kedua yang berpasangan itu. Dia juga digunakan menunjukkan hal yang sama bagi selain binatang seperti alas kaki.

11 M.Quraish Shihab, Tafsir al-Mishbah, cet I, Jilid XI (Jakarta : Lentera Hati, 1423 H-2003 M), 538. 
Selanjutnya ar-Raghib menegaskan, bahwa keberpasangan tersebut bisa akibat kesamaan dan bisa juga karena bertolak belakang. Itu dari segi bahasa. Ayatayat Al-Qur'an pun menggunakan kata tersebut dalam pengertian umum, bukan hanya untuk makhluk hidup. ${ }^{12}$

Dalam ayat 36 Yasin ini, ternyata M.Quraish Shihab juga menafsirkan kata al-azwaj (الازواج) dengan pasangan. Pasangan tersebut digunakan untuk dua hal yang berdampingan atau bersamaan. Bersamaan bisa akibat kesamaan dan bisa juga karena bertolak belakang, bermakna jantan atau betina, laki-laki atau perempuan bahkan untuk selain binatang dan manusia, seperti pasangan alas kaki.

Ibnu Katsir menafsirkan ayat 36 Yasin tersebut adalah "Maha suci Tuhan yang telah menciptakan pasangan-pasangan semuanya, baik dari apa yang ditumbuhkan oleh bumi" berupa palawija, buah-buahan dan tanaman lain, "dan dari diri mereka" dengan menjadikan mereka terdiri atas laki-laki dan perempuan, "maupun dari apa yang tidak mereka ketahui", yaitu aneka makhluk yang demikian banyak dan tidak diketahui. ${ }^{13}$

Ternyata Ibnu Katsir juga menafsirkan kata " الازواج" dengan makna pasangan terdiri atas laki-laki dan perempuan. Penafsiran Ibnu Katsir ini hampir sama dengan penafsiran al-Qurthuby, bahwa kata "الازواج" ditafsirkan dengan pasangan-pasangan dari diri mereka dan dari mereka itu diciptakan laki-laki dan perempuan. ${ }^{14}$ Jadi pasangan menurut al-Qurthuby adalah laki-laki dan perempuan.

12 M.Quraish Shihab, Tafsir al-Mishbah, cet I, Jilid XI (Jakarta : Lentera Hati, 1423 H-2003 M), 992.

13 Katsir, Tafsir Al-Qur'an al-'Azhim, jilid III (t.tp.: Maktabah alTawfiqiyah, t.t), 992.

${ }^{14}$ al-Qurthuby, al-Jami' li Ahkam al-Qur'an, (t.tp.: t.p., t.t). 
Dalam tafsir Depag RI dikatakan, bahwa kata " الازواج" dalam surah Yasin ayat 36 berarti pasanganpasangan, baik pasangan jenis, yaitu laki-laki dan perempuan, maupun berpasangan sifat, seperti besar dan kecil, kuat dan lemah, tinggi dan rendah, kaya dan miskin dan lain sebagainya. ${ }^{15}$

Dari beberapa penafsiran para ulama tafsir terhadap surah Yasin yang telah disebutkan, semuanya mengatakan bahwa makna kata "الازواج" adalah pasangan, baik pasangan laki-laki dan perempuan, maupun pasangan jantan dan betina, bahkan pasangan yang menunjukkan sifat, seperti besar dan kecil, kuat dan lemah dan sebagainya.

3) Q.S al-Dzariyat : 49 dan penafsirannya

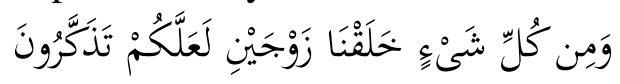

Artinya : "Dan segala sesuatu Kami ciptakan berpasang-pasangan supaya kamu mengingat kebesaran Allah".

Ibnu Katsir menafsirkan ayat tersebut sebagai berikut : "Dan segala sesuatu Kami ciptakan berpasangpasangan", yaitu semua makhluk itu adalah berpasangan : langit dengan bumi, malam dan siang, matahari dan bulan, daratan dan lautan, terang dan gelap, iman dan kufur, mati dan hidup, celaka dan bahagia, surga dan neraka, hingga hewan-hewan dan tumbuh-tumbuhan. ${ }^{16}$

Dengan demikian, maka menurut Ibnu Katsîr, bahwa kata "زوجين" adalah berarti pasangan laki-laki dan perempuan. Menurutnya hewan-hewan dan tumbuhtumbuhan pun berpasang-pasangan bahkan semua makhluk berpasang-pasangan dan semuanya dengan makna yang berlawanan, seperti pasangan malam adalah siang, pasangan matahari adalah bulan dan lain-lain. 2007).

${ }^{15}$ Depag Rl, Al-Qur'an dan Tafsirnya, Jilid VII, (Jakarta : Balitbang,

16 Katsir, Tafsir Al-Qur'an al-'Azhim, jilid IV (ttp.: Maktabah alTawfiqiyah, t.t), 237 dan Katsir, Tafsir Al-Qur'an al-'Azhim, jilid III (ttp.: Maktabah al-Tawfiqiyah, t.t), 571. 
Penafsiran Ibnu Katsir terhadap kata "زوجين" sama dengan penafsiran M. Quraish Shihab, hanya berbeda dalam pemberian sebagian contoh dan redaksi. M Quraish Shihab memberikan contoh yang berpasangan, seperti ada malam ada siang, ada atas ada bawah, demikian seterusnya. Semua selama dia makhluk memiliki pasangan. Hanya sang khalik, Allah Swt yang tidak ada pasangannya, tidak ada pula sama-Nya.

Dari segi ilmiah menurut M.Quraish Shihab terbukti bahwa listrik pun berpasangan, ada arus positif dan ada juga arus negatif, demikian juga atom, yang tadinya diduga merupakan wujud yang terkecil dan tidak dapat terbagi, ternyata iapun berpasangan. Atom terdiri dari elektron dan proton. ${ }^{17}$ Ternyata M.Quraish Shihab juga mengartikan "زوجين" adalah pasangan yang berlawanan, termasuk manusia adalah terdiri dari laki-laki dan perempuan. ${ }^{18}$

Dari penafsiran-penafsiran para ulama tafsir yang telah dikemuka-kan di atas, yaitu penafsiran terhadap Q.S al-Rum:21, Yasin : 36 dan al-Dzariyat:49, semuanya

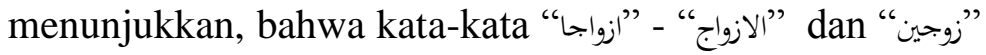
adalah berarti pasangan laki-laki dan perempuan. Tidak ada satu pun di antara ulama tafsir yang mengatakan, bahwa kata-kata tersebut berarti pasangan laki-laki dengan laki-laki (homo), atau pasangan perempuan dengan perempuan (lesbi).

Dengan demikian, maka tidak benarlah ungkapan yang mengatakan bahwa pasangan yang disebutkan dalam surah al-Rum:21, Yasin:36 dan al-Dzariyat:49, tidak hanya pada pasangan hetero (laki-laki dan perempuan), melainkan bisa homo dan bisa lesbi. Ungakapan ini adalah suatu pandangan yang menyesatkan, karena bertentangan dengan nash-nash Al-Qur'an dan Hadis serta kesepakatan ulama Islam sedunia yang mengatakan bahwa homoseks dan lesbian haram hukumnya dan pelakunya harus diberi hukuman atau sanksi.

17 M.Quraish Shihab, Tafsir al-Mishbah, cet I, Jilid XI (Jakarta : Lentera Hati, 1423 H-2003 M), 539.

${ }^{18}$ Lihat Penafsiran M. Quraish Shihab terhadap Q.S. al-Rum: 21. 
Para ulama berbeda pendapat hanya dalam menetapkan jenis hukuman atau sanksi yang dikenakan kepada pelaku homoseks. Sedangkan kepada para pelaku lesbian para ulama sepakat mengatakan, bahwa hukuman atau sanksi yang dikenakan kepada mereka adalah ta'zir, yaitu hukuman yang berat atau ringannya diserahkan kepada kebijaksanaan pemerintah (hakim).

Jadi pelaku homoseks dan lesbian bukan masalah khilafiyah (perbedaan pendapat ulama fikih dalam menetapkan hukumnya), karena ada larangan langsung dari Al-Qur'an dan Hadis, kemudian diikuti dengan kesepakatan ulama sedunia tentang keharaman perbuatan homo dan lesbi tersebut.

Perbuatan homo dan lesbi bertentangan pula dengan Pancasila dan UUD 1945 serta Undang-undang No. I Tahun 1974 tentang perkawinan serta KHI bidang perkawinan, yang mengatakan bahwa pasangan yang menikah adalah laki-laki dan perempuan. Bukan pasangan homo, atau lesbi yang melakukan perkawinan sebagaimana beberapa tahun terakhir ini, sudah ada pasangan sesama jenis melakukan perkawinan yaitu sejak tahun 2003. Dikalangan homoseks menyebut adanya 4000 hingga 5000 orang homo di Jakarta. Sedangkan gaya Nusantara memperkirakan 260.000 dari enam juta penduduk Jawa Timur adalah homo.

Bahkan Dede Oetorno memperkirakan secara nasional jumlahnya telah mencapai sekitar $1 \%$ dari total penduduk Indonesia. ${ }^{19}$ Hal tersebut terjadi tentu karena iman lemah, tidak mengetahui ajaran agama, mana yang diperintahkan dan mana yang dilarang, sementara mereka yang melakukan penyimpangan seksual itu bahkan sudah sampai kejenjang perkawinan, tidak mau belajar atau tidak mau bertanya kepada orang-orang yang mengetahui dengan baik ajaran Islam, apakah yang mereka perbuat itu dibenarkan oleh ajaran Islam atau tidak dibolehkan.

${ }^{19}$ Lihat Suara Islam, Edisi 42 tanggal 18 April-1 Mei 2008 M/11-24 Rabiul Akhir 1429 H, 13. 


\section{Hukuman/Sanksi Atas Pelaku Penyimpangan Seksual (Homoseksual/gay dan Lesbian)}

Ulama berbeda pendapat dalam menetapkan jenis hukuman sanksi yang dikenakan kepada pelaku homo dan lesbi itu kepada tiga pendapat.

Pendapat pertama mengatakan bahwa para pelaku homosek harus dibunuh. Pendapat ini dianut oleh sahabat-sahabat Nabi Saw, al-Nashir dan Qasim bin Ibrahim serta Imam Syafi'i dalam salah satu riwayat. ${ }^{20}$ Argumentasi mereka berdasarkan hadits riwayat Nasai dan Ibnu Majah dari Ibnu Abbas:

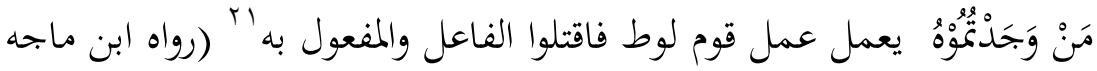

$$
\text { عن ابن عباس) }
$$

Artinya : "Siapa yang kalian temukan melakukan perbuatan seperti perbuatan Kaum Luth (perbuatan homoseksual), maka bunuhlah pelakunya dan pasangannya karena perbuatan itu. (HR. Ibnu Majah dari Ibnu Abbas)

Pendapat kedua dikemukakan oleh Imam al-Syafi'i dalam pendapatnya yang populer bahwa pelaku liwath harus dirajam tanpa membedakan apakah pelakunya itu masih bujangan ataukah sudah menikah. Pendapat kedua ini juga dikemukakan oleh Sa'id bin Musayyab (w. 94 H). 'Atha' bin Abi Rabah (w. 114 H), Hasan Abu Qatadah (w. 118 H), al-Nakhai, Sufyan al-Sauri, Abdurrahman al-Auza'i, Abi Talib, Imam Yahya dan sebagian ulama mazhab Syafi'i, hukuman terhadap pelaku homoseks sesama pria itu sama dengan hukuman ( $\mathrm{had}$ ) zina.

Mereka berpendapat bahwa kepada pelakunya diberlakukan hukuman zina, yaitu dicambuk bagi yang masih bujangan dan dirajam (dilempar dengan batu sampai wafat) bagi mereka yang sudah menikah. Argumentasi yang mereka ajukan adalah bahwa perbuatan homoseks dalam bentuk liwath/sodom itu termasuk dalam kategori perbuatan zina. ${ }^{22}$

${ }^{20}$ Sayid Sabiq, Fiqh al-Sunnah, Jilid II (t.tp : Dar al Kitab al-IslamyDar al hadis, t,t.), 366.

${ }^{21}$ Ibnu Majah, Sunan Ibnu Majah, Jilid II, 856, hadis No. 2561.

${ }^{22}$ Sayid Sabiq, Fiqh al-Sunnah, Jilid II (t.tp : Dar al Kitab al-IslamyDar al hadis, t,t.), 367. 
Imam Nawawi al-Bantani (w.1314 H/1897 M; muffasir Indonesia asal Banten) juga mengelompokkan homoseks sesama pria ke dalam perbuatan zina. Hal ini terutama dikaitkan dengan surah al-Mu'minun (23) ayat 5-7:

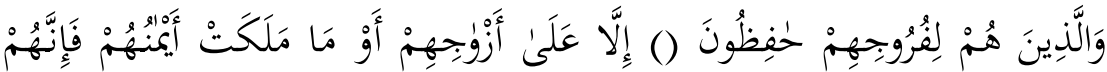

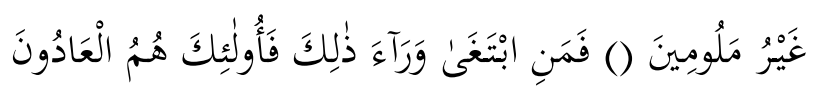

Artinya: "Dan orang-orang yang menjaga kemaluannya, kecuali terhadap isteri-isteri mereka atau budak yang mereka miliki; maka sesungguhnya mereka dalam hal ini tiada tercela. Barang siapa mencari yang dibalik itu, maka mereka itulah orang-orang yang melampaui batas".

Dalam ayat ini dan ayat sebelumnya, Allah Swt telah menjelaskan bahwa kebahagiaan seseorang hamba Allah Swt itu amat tergantung pada pemeliharaan kemaluannya dari berbagai penyalahgunaannya supaya tidak termasuk orang-orang yang tercela.

Menahan ajakan hawa nafsu jauh lebih ringan daripada menanggung akibat buruk dari perbuatan zina atau homoseks tersebut. Allah Swt telah memerintahkan Rasulullah Saw agar menyampaikan perintah itu kepada umatnya agar mereka menjaga pandangannya dengan cara memejamkan mata dan memelihara kemaluannya. ${ }^{23}$ Sebagaimana firman Allah Q.S anNur (24) : 30, 31.

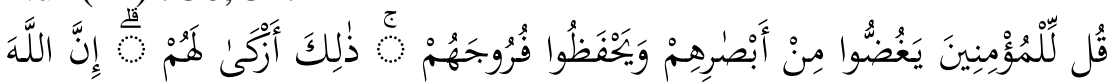

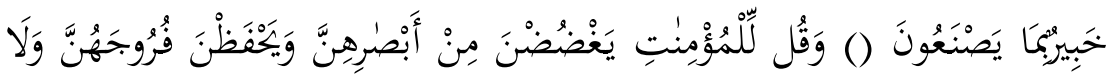

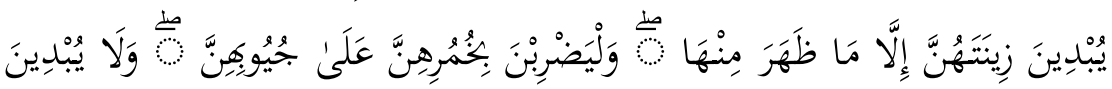

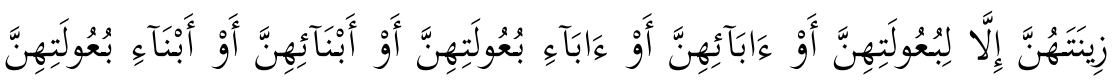

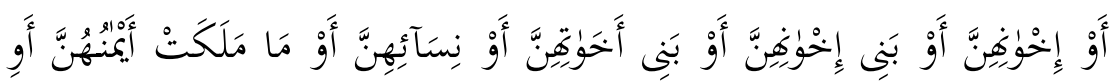

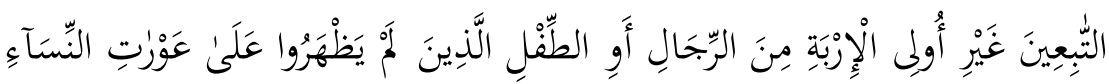

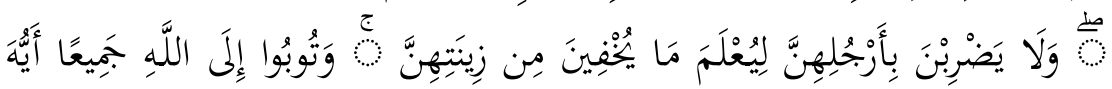

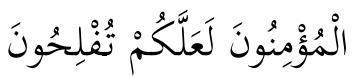

${ }^{23}$ Abd. Aziz Dahlan, et.al, (editor), Ensiklopedi Huum Islam (Jakarta: PT. Ikhtiar Van Hoeve, 1996), 564. 
Artinya : "Katakanlah kepada orang laki-laki yang beriman: "Hendaklah mereka menahan pandanganya, dan memelihara kemaluannya; yang demikian itu adalah lebih suci bagi mereka, Sesungguhnya Allah Maha mengetahui apa yang mereka perbuat". Katakanlah kepada wanita yang beriman: "Hendaklah mereka menahan pandangannya, dan kemaluannya, dan janganlah mereka menampakkan perhiasannya, kecuali yang (biasa) nampak dari padanya dan hendaklah mereka menutupkan kain kudung kedadanya, dan janganlah menampakkan perhiasannya kecuali kepada suami mereka, atau ayah mereka, atau ayah suami mereka, atau putera-putera mereka, atau putera-putera suami mereka, atau saudara-saudara laki-laki mereka, atau putera-putera saudara lelaki mereka, atau puteraputera saudara perempuan mereka, atau wanita-wanita Islam, atau budak-budak yang mereka miliki, atau pelayan-pelayan lakilaki yang tidak mempunyai keinginan (terhadap wanita) atau anak-anak yang belum mengerti tentang aurat wanita. dan janganlah mereka memukulkan kakinya agar diketahui perhiasan yang mereka sembunyikan. dan bertaubatlah kamu sekalian kepada Allah, Hai orang-orang yang beriman supaya kamu beruntung.

Pendapat ketiga menyatakan bahwa hukumannya diserahkan kepada penguasa. Pendapat ini dianut oleh Imam Abu Hanifah, Mu'ayyad Billah, dan al-Murtadha, keduanya ahli fikih Syiah dan Imam Syafi'i dalam riwayat yang lain. Penguasalah yang berhak menetapkan jenis hukumannya, karena perbuatan tersebut tidak dapat dikategorikan ke-dalam perbuatan zina, maka hukumannya pun tidak dapat disamakan dengan hukuman zina. ${ }^{24}$

Menurut al-Syaukani, pendapat pertama yang kuat, karena berdasarkan nas sahih, sedangkan pendapat kedua dianggap lemah, karena Hadis yang dipakainya lemah. Demikian pula pendapat ketiga, juga dipandang lemah, karena bertentangan dengan nas yang telah menetapkan hukuman mati (hukuman had), bukan hukuman ta'zir. ${ }^{25}$

${ }^{24}$ Al-Sayyid Sabiq, Fiqh Al Sunnah, Jilid II (Dar al Kitab al Islamy-Dar al Hadis, t,t), 369.

${ }^{25}$ Abd. Qadir Audah, al-Tasyri' al-Jinai al Islamy (Iskadariah : Dar Nasyr al Tsaqafiyyah, 1949), 186. 
Sedangkan hukuman bagi pelaku lesbi, ulama sepakat

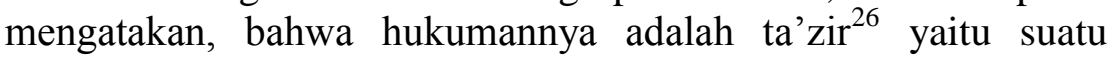
hukuman yang macam dan berat ringannya diserahkan kepada pengadilan. Jadi, hukumannya lebih ringan daripada homoseksual, karena bahaya atau resikonya lebih ringan dibandingkan dengan bahaya homoseksual, karena lesbian itu hanya bersentuhan langsung tanpa memasukkan alat kelaminnya; seperti halnya pria.

Dalam kitab Undang-Undang Hukum Pidana (KUHP) Pelanggaran terhadap kesucian melalui perbuatan homoseks (sodomi), pada pasal 292 disebutkan:

Orang dewasa yang melakukan perbuatan cabul dengan orang lain sesama kelamin, yang diketahuinya atau sepatutnya harus diduganya belum dewasa, diancam dengan ancaman pidana penjara paling lama lima tahun.

Di Indonesia, larangan hubungan seksual sesama jenis kelamin (homoseksual) hanya terhadap orang yang melakukannya dengan anak yang belum dewasa. Jika homoseksual itu dilakukan oleh orang-orang yang sama-sama dewasa dan sama-sama suka, maka hubungan homoseksual itu tidak dapat dilarang.

Tetapi masyarakat tidak atau belum dapat menerima pemikiran ini, karena hubungan homoseksual itu, menurut hukum pidana Islam khususnya, adalah merupakan hukuman pidana yang dapat dikenakan hukuman jika terbukti. ${ }^{27}$

Sebagaimana telah dijabarkan di atas, bahwa dalam rangka penerapan tehadap hukuman dan untuk melindungi masyarakat dari kekejian perilaku, maka dibutuhkan kekuasaan dan kedaulatan untuk dapat menegakkannya. Di Indonesia, sebagaimana pasal 292 dalam KUHP di atas, dikatakan sanksi hukuman untuk perbuatan cabul sesama jenis kelamin (dalam hal ini sodomi) hanya diberlakukan bagi pelaku yang melakukan perbuatan keji itu dari orang dewasa kepada anak yang dibawah umur.

${ }^{26}$ Al-Sayyid Sabiq, Fiqh Al Sunnah, Jilid II (Dar al Kitab al Islamy-Dar al Hadis, t,t), 369.

${ }^{27}$ Nang Djubaedah, Perzinaan Dalam peraturan Perundang-Undangan di Indonesia ditinjau dari Hukum Islam (Jakarta : kencana Prenada Media Group, 2010), 80. 
Namun apabila perbuatan ini dilakukan oleh orang yang dewasa dan sama-sama suka maka hukuman tersebut di atas tidak diberlakukan. Ini jelas sangat bertentang dengan Al-Qur'an dan Hadits sebagai dasar utama penerapan hukum Islam, bahkan bertentangan dengan Pancasila, UUD 1945 dan UU No. 1 Tahun 1974 Tentang Perkawinan dan KHI Bidang Perkawinan.

Secara tidak langsung hubungan seks sesama jenis di Indonesia dari pasal 292 KUHP ini masih diperbolehkan kecuali terhadap orang yang telah ditentukan pelarangannya. Untuk selanjutnya, ketika diajukan Rancangan Undang-undang Kitab Undang-Undang Hukum Pidana (RUU KUHP) di tahun 2008, maka pelanggaran seperti ini pun kembali ditetapkan hukumannya, masih mengadopsi pasal 292 dalam RUU KUHP pasal 494 bunyinya menjadi.

"Setiap orang yang melakukan perbuatan cabul dengan orang lain yang sama jenis kelaminnya yang diketahui atau patut diduga belum berumur 18 tahun, dipidana dengan pidana penjara paling singkat 1 tahun dan paling lama 7 tahun."

Pada pasal 292 KUHP dan pasal 494 RUU-KUHP 2008 ditemukan adanya perbedaan pada segi hukuman dan batasan umur orang yang dapat dijadikan pasangan homoseksual.

1) Segi hukuman, pasal 292 KUHP menentukan hukuman penjara paling lama lima tahun, sedangkan pasal 494 RUUKUHP 2008 menentukan hukuman pidana paling singkat satu tahun dan paling lama tujuh tahun.

2) Segi usia, pasal 292 KUHP menentukan batasan usia orang yang dapat dijadikan pasangan homoseksual adalah "yang diketahuinya atau sepatutnya harus diduganya belum dewasa", pasal 494 RUU-KUHP 2008 disebutkan secara tegas bahwa pasangan homoseksual adalah orang yang berumur 18 tahun. ${ }^{28}$

${ }^{28}$ Nang Djubaedah, Perzinaan Dalam peraturan Perundang-Undangan di Indonesia ditinjau dari Hukum Islam (Jakarta : kencana Prenada Media Group, 2010), 91. 
Sebetulnya isi pasal yang sampai hari ini belum diberlakukan di Indonesia tersebut tidak berbeda jauh dengan pasal sebelumnya pada KUHP, bahwa perbuatan homoseksual masih diperbolehkan, hanya saja bentuk hukumannya yang berbeda dan terhadap pelaku dibawah umur 18 tahun. Artinya adalah apabila pelaku melakukannya di atas umur 18 tahun dan suka sama suka hukuman tetap saja tidak bisa diberlakukan.

Akan tetapi lain halnya apabila perbuatan homoseksual (meliputi gay dan lesbian) ditemui di Nanggroe Aceh Darussalam. Di propinsi paling ujung di Indonesia ini, ditetapkan dan diterapkan hukum Islam sebagai undangundang khusus di propinsi tersebut yang disebut dengan Qanun Hukum Jinayat Aceh (QHJA).

Dalam Qanun Hukum Jinayat Aceh, ditemukan ketentuan pelanggaran terhadap perzinaan terkait dengan homoseksual. Sebagaimana diketahui, Qanun Hukum Jinayat Aceh telah disahkan oleh Dewan Perwakilan Rakyat Aceh pada tanggal 14 September 2009. ${ }^{29}$

Pada Pasal 34 dalam QHJA juga disebutkan, setiap orang dengan sengaja melakukan jarimah sebagaimana dimaksud dalam pasal 33 terhadap anak-anak diancam dengan 'uqubat ta'zir' paling banyak 200 (dua ratus) kali cambuk dan denda paling banyak 2.000 (dua ribu) gram emas murni atau penjara paling lama 200 (dua ratus) bulan. ${ }^{30}$

Jelas sudah dalam QHJA ini, bahwa pelanggaran terhadap tindak homoseksual baik yang dilakukan oleh lakilaki maupun perempuan akan dikenakan pada setiap orang, baik itu dianggap sudah dewasa atau belum, bahkan meskipun hal itu dilakukan dengan dasar suka sama suka.

${ }^{29}$ Nang Djubaedah, Perzinaan Dalam peraturan Perundang-Undangan di Indonesia ditinjau dari Hukum Islam (Jakarta : kencana Prenada Media Group, 2010), 102

${ }^{30}$ Nang Djubaedah, Perzinaan Dalam peraturan Perundang-Undangan di Indonesia ditinjau dari Hukum Islam (Jakarta : kencana Prenada Media Group, 2010), 336, 337. 


\section{E. Dampak Penyimpangan Seksual (Homosek dan Lesbian)}

Penyimpagan seksual dampaknya membahayakan diri pelakunya, pasangannya dan lain-lain. Jika dahulu penduduk Sadum dihancurkan dengan kehancuran yang dahsyat akibat perbuatan mereka, maka saat ini bisa dilihat dampak negatif dari perilaku homoseksual adalah munculnya penyakit yang diakibatkan oleh virus yang menyerang kekebalan tubuh manusia, virus ini dikenal dengan nama HIV dan penyakit yang ditimbulkan karenanya adalah AIDS.

HIV dan AIDS adalah jenis penyakit baru yang ditemukan di sekitar tahun 1980-an di kota-kota besar di Amerika Serikat. HIV merupakan singkatan dari Human Immunodeficiency Virus, sedangkan AIDS merupakan singkatan dari Acquired Immune Deficiency Syndrome.

Jadi HIV merupakan virus yang menyebabkan penyakit AIDS. Penyakit ini merupakan penyakit kelamin yang pada mulanya dialami oleh kelompok kaum homoseksual. ${ }^{31}$

Pada tahun 1985 dokter Robert Gallo menemukan sejenis penyakit yang diberi nama gay related immune deficiency syndrome, yaitu gejala penyakit yang disebabkan penurunan kekebalan tubuh yang berhubungan dengan kelompok homoseksual.

Gejala yang menyolok pada penyakit ini berupa tumor kulit berwarna ungu yang disebut juga dengan istilah sarcoma kaposi, atau disebut juga sebagai gay plague yaitu wabah mematikan yang menimpa kaum homoseksual. Selain daripada itu ada gejala lain yang disebut gay pneumonia yaitu radang paruparu disebabkan parasit yang berkembang dan mematikan.

Penyebaran penyakit ini begitu cepat, hingga hari ini belum ada ahli yang dapat menemukan obat apa yang bisa mengobati penyakit ini. Dadang Hawari menuliskan bahwa HIV/AIDS itu memiliki global effect. ${ }^{32}$

${ }^{31}$ Dadang Hawari, Global Effect HIV/AIDS Dimensi Psikoreligi, Cet II (Jakarta: Balai Penerbit FKUI 2009), 2.

${ }^{32}$ Disebut global effect karena penyebaran penyakit ini begitu cepat mendunia. Penyakit yang pada awalnya ditemukan di Amerika Serikat kini hampir ditemui di seluruh belahan dunia. 
Ia mengatakan penyakit ini pada awalnya menjangkiti para laki-laki yang memiliki gaya hidup homoseksual. Penyakit AIDS kemudian melalui kaum homoseksual yang berfungsi ganda (bisexual) menulari perempuan-perempuan pelacur, dari sini menulari lagi para pelanggannya laki-laki normal, kemudian menulari lagi laki-laki dan perempuan yang melakukan hubungan perzinaan (seks bebas, perselingkuhan, dan pacaran), dari sini kemudian menulari ibu-ibu rumah tangga dan bayi-bayi yang dikandungnya.

Dengan kecepatan penularan I menit 5 orang tertular akhirnya penyakit HIV/AIDS ini melesat dan menyebar dari pantai Barat ke pantai Timur Amerika dan akhirnya ke seluruh dunia, sampai di Indonesia pada tahun $1987 .{ }^{33}$ Peristiwa ini merupakan global effect dengan kematian yang mengenaskan. ${ }^{34}$

Penyakit yang mula-mula disebarkan oleh para pelaku homoseksual di Amerika Serikat itu, pada akhirnya tidak hanya menjangkiti laki-laki yang melakukan praktik homoseksual tetapi juga menyebar kepada laki-laki biseksual atau heteroseksual hingga kepada ibu-ibu, bahkan kepada janin dan bayi-bayi yang dilahirkan dari seorang ibu yang mengidap virus tersebut. Penyakit ini juga bisa menjangkiti siapa saja yang tidak berdosa melalui pertukaran cairan (sperma atau transfusi darah).

${ }^{33}$ Pada tahun 1987 ditemukan kasus kematian pertama di Indonesia karena penyakit ini, Seorang wisatawan asal Belanda meninggal di RS Sanglah, Bali. Kematian pria berusia 44 tahun itu diakui Depkes disebabkan AIDS. Indonesia masuk daiam daftar WHO sebagai negara ke-13 di Asia yang melaporkan kasus AIDS. Sebenaranya penelitian tentang HIV/AIDS di Indonesia sendiri sudah terjadi di tahun 1983, Dr. Zubairi Djoerban melaksanakan penelitian terhadap 30 waria di Jakarta. Karena rendahnya tingkat limfosit dan gejala klinis, Dr. Zubairi menyatakan dua di antaranya kemungkinan AIDS. Lihat http://spiritia.or.id/art/bacaart.php?artno=1040. artikel diakses tanggal 20 Januari 2011

${ }^{34}$ Dadang Hawari, Global Effect HIV/AIDS Dimensi Psikoreligi, Cet II (Jakarta : Balai Penerbit FKUI 2009), 3. 
Dampak negatif bagi pelaku homoseksual tidak hanya ancaman penyakit HIV/AIDS yang juga berdampak besar di masyarakat. Tetapi masih banyak lagi jenis penyakit kelamin yang akan menimpa para pelaku seks menyimpang, antara lain “

1) Sifilis atau raja singa. Ini adalah penyakit kelamin yang disebabkan oleh treponema pallidum yang berbahaya bagi penderita dan keturunannya. ${ }^{35}$ Penyakit sifilis dapat menyebar melalui persenggamaan vaginal atau anal (jalan belakang), seks oral, ciuman dan kontak kulit dengan kulit. ${ }^{36}$

2) Gonorrhea (kencing nanas). Ini adalah salah satu penyakit kelamin yang berbahaya yang biasanya dilakukan oleh orangorang yang melakukan hubungan seks tanpa aturan. Penyakit kelamin ini mudah menular akibat peradangan yang disebabkan oleh bakteri gonokukus, neisseria gonorrhoeae. Masa inkubasinya sekitar 2-7 hari. Gejala Gonorrhea lebih jelas terlihat pada pria, seperti keluarnya nanah dari saluran kencing yang terasa membakar. ${ }^{37}$ Penyakit yang menyerang alat kelamin ini termasuk dalam salah satu faktor yang membuat seseorang mandul, juga menyebabkan penyakit kencing batu, juga menyebabkan penderita merasa kesakitan ketika ingin kencing, sakit kepala yang pada akhirnya merusak paru-paru, hati, dan lambung. ${ }^{38}$

3) Uretritis dan Klamidia Nonspesifik Nongonococcal, adalah kondisi-kondisi medis yang menyebabkan perdangan uretra pria. Penyakit ini paling umum berkembang dari mikroorganisme mirip bakteri yang disebut clamydia trachomatis. Infeksi klamidia ditularkan melalui seks oral, vaginal, dan anal. ${ }^{39}$

${ }^{35}$ Abu Ameenah Bilal Philips dan Zafar Khan, Islam dan Homoseksual, Penj. Yudi (Jakarta : Pustakan Azzahra, 2003), 26.

${ }^{36}$ Killingstone dan Cornellis Sex and Love Guide to Teenagers-101\% untuk Remaja (Jakarta : Prestasi Pustaka Raya, 2008), 189.

37 Philip and Khan, Islam dan Homoseksual (Jakarta : Pustaka AzZahra, 2003), 26.

${ }^{38}$ Muhammad bin Ibrahim Al-Hamidi Az-Zulfi, Homoseks. 1h....Takut. Penj. Roni Mahmuddin (Jakarta: Hikmah (Mizan Publika), 2005), 38.

${ }^{39}$ Killingstone dan Cornellis Sex and Love Guide to Teenagers-101\% untuk Remaja (Jakarta : Prestasi Pustaka Raya, 2008), 192. 
4) Herpes Genital (herpes kelamin) adalah penyakit pada kulit di daerah kemaluan, disebabkan oleh virus herpes simpleks. Ditandai dengan gelembung-gelembung kecil berisi getah bening, letaknya berkumpul, dan terasa membakar. Terkadang disertai gejala sakit kepala, gatal-gatal, dan demam. ${ }^{40}$

5) Hepatitis B. seperti HIV, virus hepatitis B dalam darah dan cairan-cairan tubuh dan dapat ditularkan melalui hubungan seksual, dengan menggunakan jarum suntik bersama-sama atau dengan menerima tarnsfusi darah yang telah terinfeksi. ${ }^{41}$ Penyakit ini menyerang sel-sel hati (lever) dan dapat menyebabkan cirrhosis atau bahkan kanker hati. ${ }^{42}$

Homoseksual tidak hanya menimbulkan bahaya untuk pribadi atau individu yang melakukan praktik hidup demikian saja, tetapi juga secara kesehatan bisa menimbulkan dan menulari virus-virus berbahaya kepada siapa saja.

Selain dampak secara kesehatan, homoseksual juga berdampak pada kehidupan sosial, politik, ekonomi, sosiologis, psikologis bahkan juga secara keagamaan. misalnya.

Pertama, suatu masyarakat yang di dalamnya terdapat pelaku homoseksual, maka akan menimbulkan hilangnya keberkahan dan rasa aman, karena tersebarnya kerusakan di masyarakat.

Kedua, berdasarkan pesan Al-Qur'an, bahwa suatu tindakan dosa akan mendatangkan musibah dan azab bagi pelakuknya di suatu negeri. Jika itu telah terjadi maka azab itu tidak hanya menimpa kaum yang berdosa saja tetapi juga mengenai pada mereka yang beriman.

Ketiga, dikhawatirkan juga munculnya wabah penyakit akibat perilaku seks menyimpang secara luas di masyarakat, penyakit-penyakit tersebut bisa menulari siapa saja bahkan kepada seseorang yang tidak tersangkut sema sekali dengan tindakan menyimpang tersebut.

${ }^{40}$ Killingstone dan Cornellis Sex and Love Guide to Teenagers-101\% untuk Remaja (Jakarta : Prestasi Pustaka Raya, 2008), 27.

${ }^{41}$ Killingstone dan Cornellis Sex and Love Guide to Teenagers-101\% untuk Remaja (Jakarta : Prestasi Pustaka Raya, 2008), 197.

${ }^{42}$ Killingstone dan Cornellis Sex and Love Guide to Teenagers-101\% untuk Remaja (Jakarta : Prestasi Pustaka Raya, 2008), 27. 
Keempat, tindakan homoseksual bisa merusak moral dan akhlak, memicu memunculkan goncangan jiwa dan kelamahan sel-sel syaraf karena pelaku homoseksual hanya mengedapankan pelampiasan terhadap hawa nafsu saja.

Kelima, orang yang memilki penyakit homoseksual dan tidak ada niat untuk menyembuhkannya akan ada dalam tekanan dan merasa terkucilkan dalam masyarakat, yang bisa mengakibatkan pergaulannya terbatasi. Sebaliknya orang yang menjadikan perilaku homoseksual sebagai gaya hidupnya di khawatirkan akan mempengaruhi lingkungan dan orang-orang di sekelilingnya.

Keenam, pelaku homoseksual yang coming out di masyarakat dan turut berpartisipasi dalam kehidupan sosial kemasyarakatan bisa mendorong dibentuknya aturan dan hukum yang bisa melegalkan perilaku homoseksual, padahal secara agama dan moral perilaku ini jelas-jelas terlarang.

Ketujuh, banyaknya pelaku homoseksual bisa mempengaruhi struktur kemasyarakatan dan bisa membawa pada perubahan sosial yang bisa mengarahkan masyarakatnya untuk menerima hidup berdampingan dengan perilaku penyimpangan seksual lainnya dengan dalih hak asasi atas kehidupan yang disamaratakan.

Kedelapan, pelaku homoseksual yang memperturutkan hawa nafsunya juga menderita kerugian secara ekonomi karena akan berusaha menuruti keinginannya setiap saat (melalui prostitusi atau tindakan munkar lainnya).

Kesembilan, tindakan homoseksual juga bisa merusak kehormatan dan kesucian dari laki-laki akibat pelampiasan hawa nafsu yang berlebih-lebihan. Selain itu juga tindakan homoseksual bisa merusak kehormatan dan kemuliaan dari wanita (isteri-isteri) karena mereka ditinggalkan oleh laki-laki yang tidak meninggikan akhlak mereka. Akibat tindakan homoseksual dari laki-laki juga menjadi penyebab munculnya tindakan homoseksual antar-wanita yang disebut dengan lesbianisme. 
Kesepuluh, tindakan homoseksual bisa mengurangi jumlah anggota masyarakat karena terputusnya jalur perkembangbiakkan manusia (tidak adanya keturunan). Hubungan seks antara sesama jenis selain telah melanggar batas kefitrahan dan kepatutan terhadap hubungan seks, juga bisa memutus mata rantai kelanjutan generasi kemanusiaan. Karena salah satu tujuan dari hubungan seks yang manusiawi adalah untuk perkembangbiakkan manusia, sementara tindakan homoseksual tidak akan melahirkan generasi baru yang bisa melanjutkan mata rantai kehidupan.

Itulah beberapa dampak dari perilaku homoseksual. Dampak homoseksual dewasa ini menjadikan ancaman bagi penyebaran berbagai macam penyakit kelamin yang menular, sifatnya yang menular maka segala jenis penyakit kelamin ini bisa menyebar kepada semua orang yang terkontaminasi perbuatan atau perilaku seksual menyimpang tersebut. 


\section{F. Penutup}

Artikel ini memberikan kesimpulan sekaligus merekomendasikan risalah Islam yakni: (1) Memperkuat iman dan taqwa (IMPTAQ) melalui dakwah dan pendidikan. (2) Menanamkan dan meingkatkan pendidikan akhlak yang mulia khususnya terhadap anak-anak dan masyarakat pada umumnya. (3) Meningkatkan peran orang tua terhadap kecenderungan seksualitas anak.

Penelitian dari seorang ahli di Amerika Serikat Gary Ramafedi pada tahun 1992 dari University of Minnesota, Minneapolis, Amerika Serikat, menyatakan bahwa melalui pendidikan agama sejak dini, maka peluang anak untuk menjadi homoseksual menjadi amat kecil. ${ }^{43}$ Dalam Islam pendidikan agama sangat penting, karena itu setiap orang tua muslim harus membekali diri dengan ilmu pengetahuan tentang tata cara mendidik anak.

Pada dasarnya setiap anak yang lahir di muka bumi ini dalam keadaan fitrah, maka orang tua dan keadaan lingkungannyalah yang akan mengarahkan dia untuk terbentuk menjadi identitas yang seperti apa. Terkait dengan keadaan anak yang dilahirkan dalam keadaan fitrah Rasulullah Saw menyatakan dalam sabdanya.

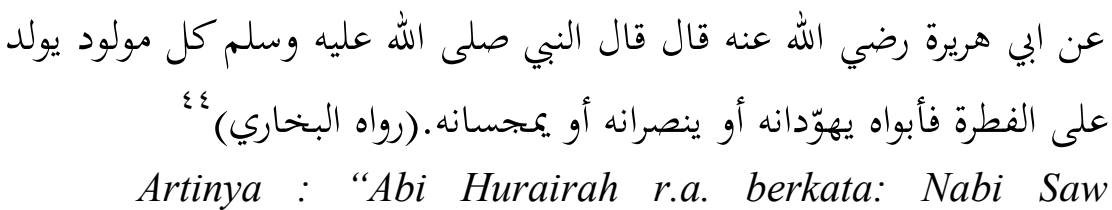
bersabda, setiap anak dilahirkan dalam keadaan fitrah, orang tuanyalah yang menjadikan dia Yahudi, Nasrani, dan Majusi. "'(H.R. al-Bukhari)“"

Pendidikan agama dan pendidikan seks untuk anak merupakan salah satu upaya antisipasi. Orang tua mengambil peranan yang sangat penting dalam hal ini. Islam juga mengatur cara memberikan pendidikan seks kepada anak, dengan cara melakukan treatment yang berbeda antara anak laki-laki dan anak perempuan.

${ }^{43}$ Dadang Hawari, Pendekatan psikoreligi., 39.

${ }^{44}$ Muhammad bin Ismail al-Bukhari, Shahih al-Bukhari, Jilid II (Bairut: Dar al-Fikr, 1999), 182. 
Misalnya dalam hal permainan, pakaian, dan Islam sendiri menganjurkan untuk memisahkan tempat tidur antara lakilaki dan perempuan ketika mereka telah menginjak usia tujuh tahun, sebagaimana Hadits Nabi Muhammad Saw berikut ini.

$$
\begin{aligned}
& \text { عن عمرو بن شعيب عن أبيه، عن جده قال: قال رسول الله صلى الله عليه } \\
& \text { وسلم: مرووا أولادكم بالصلاة وهم أبناء سبع سنين واضربوهم عليها عنها وهم أبناء } \\
& \text { عشرين سنين، وفرقوا بينهم في المضاجع (رواه أبو داود)؛ }
\end{aligned}
$$

Artinya: "Dari 'Amr bin Syu'aib, dari ayahnya, dari kakeknya yang mengatakan bahwa Rasululllah Saw bersabda: "Perintahlah anak-anakmu melakukan shalat ketika umurnya sudah sampai tujuh tahun dan pukullah jika mereka meninggalkan shalat, jika umurnya sudah sepuluh tahun dan pisahkanlah tempat tidurnya." (H.R. Abu Daud)

Pertama, menjauhi hal-hal yang dapat mengarahkan pada perilaku yang mendekatkan pada tindakan homoseksual dan lesbian.

Orang tua juga masih mengambil peranan penting dalam hal ini, menghindari hal-hal yang dapat mengarahkan seseorang melakukan tindakan homoseksual dan lesbian, yakni : (1) Melarang laki-laki melakukan hal-hal yang menyerupai tindakan perempuan, begitupun sebaliknya. Sebagaimana diterangkan dalam hadits Nabi Muhammad Saw berikut ini.

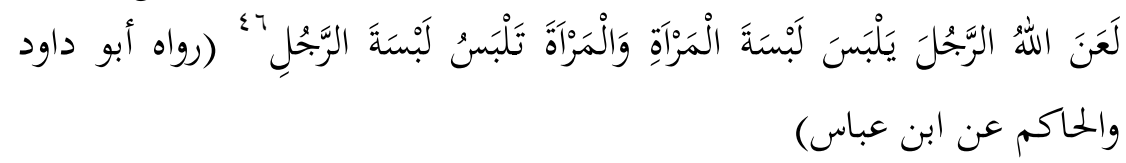

Artinya: "Allah mengutuk laki-laki memakai pakaian perempuan dan perempuan memakai pakaian laki-laki." (H.R. Abu Daud dan al-Hakim dari Ibnu Abbas).

${ }^{45}$ Jalaluddin al Suyutihy, al Jami' al Shaghir, jilid II (Beirut-Libanon, Dar al Kutub al-Ihmiyah, t.t), 155.

${ }^{46}$ Jalaluddin al Suyutihy, al Jami' al Shaghir, jilid II (Beirut-Libanon, Dar al Kutub al-Ihmiyah, t.t), 124. 
Kemudian yang ke (2) di tengah era informasi yang cukup canggih ini, orang tua atau masyarakat bisa menuntut adanya regulasi atau aturan yang mengarah kepada tindakantindakan menyerupai perilaku homoseksual baik gay maupun lesbianisme di masyarakat dan dalam semua media informasi terutama televisi, surat kabar, majalah, dan media internet. Juga menuntut untuk pembatasan akses terhadap segala tindakan pornografi maupun pornoaksi.

Kedua, menikah adalah sebuah cara untuk menyalurkan nafsu biologis sesuai dengan tuntunan agama dan sunnah Rasul. Hubungan seks memiliki berbagai tujuan mulia, selain karena harus dilakukan di dalam ikatan suci pernikahan, melalui pernikahan inilah diharapkan akan lahir generasi berikutnya sebagai bagian dari sunnatullah yaitu manusia yang semakin beranak pinak dan merupakan suatu cara untuk menjaga kehormatan dan kesucian diri.

Ketiga, menetapkan dan menerapkan hukuman dan sanksi terhadap pelaku penyimpangan seksual (homoseksual dan lesbian).

Keempat, pemerintah harus melarang segala bentuk propaganda, promosi dan dukungan terhadap legalisasi dan perkembangan LGBT di Indonesia.

Kelima, pemerintah hendaknya melarang masuknya dana asing yang diperuntukkan bagi kampanye dan sosialisasi serta dukungan bagi LGBT di Indonesia yang dilakukan oleh pihak manapun, termasuk oleh organisasi internasional serta perusahaan internasional.

Keenam, pemerintah hendaklah segera mengeluarkan peraturan perundang-undangan yang melarang prilaku dan praktek LGBT, karena hal itu mengancam eksistensi kemanusiaan dan peradaban serta masa depan umat manusia.

Ketujuh, pemerintah hendaklah meningkatkan kualitas dan kuantitas program kerja dan anggaran di bidang pendampingan, rehabilitasi serta penyembuhan bagi mereka yang tergolong LGBT.

Kedelapan, masyarakat hendaklah membantu dan melakukan pendampingan terhadap komunitas LGBT dan tidak mengucilkan mereka, agar mereka dapat kembali pada kehidupan yang wajar dan normal.

Demikian hukum dan upaya untuk mengurangi atau menanggulangi penyimpangan seksual (LGBT) yang dapat di kemukakan. 


\section{Daftar Pustaka}

Al-Bukhari, Muhammad bin Ismail, Shahih al-Bukhari, Bairut: Dar al-Fikr, 1999.

Al-Qurthuby, al-Jsml' al-Ahkam al-Qur'an, t.tp. : t.p., t.t.

Al-Suyuthy, Jalaluddin, al-Jami' al-Shaghir, Bairut-Libanon : Dar al Kutub al Ilmiyah, t.t.

Al-Tirmidzi, Sunan al-Tirmidzi, Bairut : Dar al Fikr, 1994.

Audah, Abd. Qadir, al-Tasyri' al-Jinai al Islamy, Iskadariah: Dar Nasyr al Tsaqafiyyah, 1949.

Az-Zulfi, Muhammad bin Ibrahim al-Hamidi, Homoseks. 1h....Takut. Penj. Roni Mahmuddin, Jakarta: HikmahMizan Publika, t.t.

Dahlan, Abd. Aziz, et.al., (editor), Ensiklopedi Hukum Islam, Jakarta: PT. Ikhtiar Van Hoeve, 1996.

Depag RI, Al-Qur'an dan Tafsirnya, Jakarta, Balitbang, 2007.

Djubaedah, Neng, Perzinaan Dalam peraturan PerundangUndangan di Indonesia ditinjau dari Hukum Islam, Jakarta : Kencana Prenada Media Group, 2010.

Hawari, Dadang, Global Effect HIV/AIDS Dimensi Psikoreligi, Jakarta: Balai Penerbit FKUI 2009.

Katsir, Ibnu, Tafsir Al-Qur'an al-'Azhim, t.tp.: Maktabah alTawfiqiyah, t.t.

Killingstone dan Cornellis Sex and Love Guide to Teenagers101\% untuk Remaja, Jakarta : Prestasi Pustaka Raya, 2008.

Majma' al-Lughah al-'Arabiyah, al-Mu'jam al-Wasith, Mishr : Dar al-Ma'arif, 1393 H- 1973 M.

Munawwir, Ahmad Warson, Kamus Al-Munawir, Surabaya; Pustaka Progressif, 1997.

Muslim, Shahih Muslim, Cairo: Dar al-Hadits, 1997.

Philip and Khan, Islam dan Homoseksual, Jakarta; Pustaka alZahra, 2003.

Philips, Abu Ameenah Bilal dan Zafar Khan, Islam dan Homoseksual, Penj. Yudi, Jakarta: Pustakan al-Zahra, 2003.

Sabiq, Sayid, Fiqh al-Sunnah, Dar al Kitab al Islamy-Dar al Hadis, t,t.

Shihab, M. Quraish, Tafsir al-Misbah, Jakarta : Lentera Hati, $1423 \mathrm{H}-203 \mathrm{M}$.

Suara Islam, Edisi 42 tanggal 18 April-1 Mei 2008 M/11-24 Rabiul Akhir 1429 H, 13. 